\title{
Renal Histological Alterations Induced by Acute Exposure of Titanium Dioxide Nanoparticles
}

\author{
Alteraciones Histológicas Renales Inducidas por la Exposición \\ Aguda de Nanopartículas de Dióxido de Titanio
}

Amin A. Al-Doaiss ${ }^{1,2}$; Daoud Ali³; Bahy A. Ali ${ }^{4}$ \& Bashir M. Jarrar ${ }^{5}$

\begin{abstract}
AL-DOAISS, A. A.; ALI, D.; ALI, B. A. \& JARRAR, B. M. Renal histological alterations induced by acute exposure of titanium dioxide nanoparticles. Int. J. Morphol., 37(3):1049-1057, 2019.

SUMMARY: Titanium dioxide nanoparticles $\left(\mathrm{TiO}_{2} \mathrm{NPs}\right)$ are widely used in many commercial products, nanomedicine, agriculture, personal care products, different industries and pharmaceutical preparations with potential risk in human health and the environment.

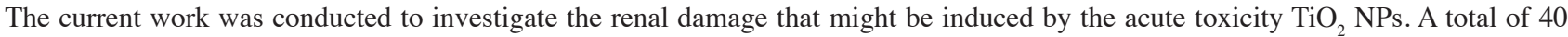

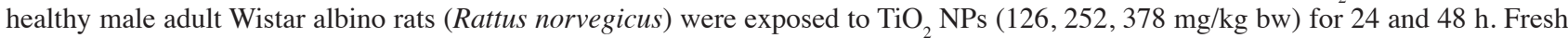
portions of the kidneys from each rat were processed for histological and histochemical alterations. In comparison with respective control rats, exposure to $\mathrm{TiO}_{2}$ NPs has marked the following glomerular, tubular and interstitial alterations including the followings: glomerular congestion, Bowman's capsule swelling and dilatation, inflamed glomeruli, renal tubules cloudy swelling, karyorrhexis, karyolysis, infiltration of inflammatory cells, congestion, necrosis, hydropic degeneration, dilatation and congestion of blood vessels, hyaline droplets and hyaline casts precipitation, interstitial edema and fibrosis. From the findings of the current work one may conclude that $\mathrm{TiO}_{2}$ NPs are capable of inducing kidney damage with more insulation in the cortex and the proximal convoluted tubules than the medulla and the distal ones respectively. In addition, it might be concluded that renal damage induced by these nanomaterials is dose and duration of exposure dependent. Further hematological, biochemical,immunohistochemical, and ultra-structural studies are recommended.
\end{abstract}

KEY WORDS: $\mathrm{TiO}_{2}$ nanoparticles; Renal tissues; Histological alterations; Hydropic degeneration; Nanotoxicity.

\section{INTRODUCTION}

Titanium dioxide NPs applications gradually are increasing in biomedical, industrial, and optical fields (Seeger et al., 2009). This is due to their low production cost, high refractive index, photostability in solutions and anticorrosive properties that make them suitable for biological, commercial and medical applications (Fartkhooni et al., 2016). Titanium oxides NPs have different sizes, shapes, chemistry and crystalline structures with special characterizations such as surface functionalization and higher stability, enabling them to be used widely in several fields in our daily life activities (Li et al., 2010).

Thousands of tons of $\mathrm{TiO}_{2}$ NPs are utilized annually in the world in different fields of commercial application such as plastics, paints, cements and other application. Some recent studies predicted that most of the currently produced $\mathrm{TiO}_{2}$ will be converted into nano forms by the end of year 2026 (Galletti, 2016). Moreover, $\mathrm{TiO}_{2}$ NPs are among the most nanomaterials used in therapy, drug delivery, engineering, agriculture, personal care products, cosmetics, sunscreens, toothpaste, electronics, clothes, paints, and covers, as imaging agent and foodstuffs (Chabanyuk, 2014; Galletti; Yang et al, 2017). In addition, $\mathrm{TiO}_{2}$ NPs are widely invested in nanomedicine and are being used in diseases diagnosis and advanced imaging and nanotherapeutics like photodynamic therapy, antimicrobial drugs and skin care products (Yuan et al., 2010).

Furthermore, several researchers have revealed the toxic impacts of $\mathrm{TiO}_{2}$ NPs on various organs (Zhao et al.,

${ }^{1}$ Department of Biology, College of Science, King Khalid University, Abha, Saudi Arabia.

${ }^{2}$ Department of Anatomy and Histology, Faculty of Medicine, Sana'a University, Sana'a, Republic of Yemen.

${ }^{3}$ Department of Zoology, College of Science, King Saud University, Riyadh, Saudi Arabia.

${ }^{4}$ Genetic Engineering and Biotechnology Research Institute, City for Scientific Research and Technology Applications, Alexandria, Egypt.

${ }^{5}$ Department of Biology, Faculty of Science, Jerash University, Jordan. 
2009). These NPs could be absorbed through inhalation, oral ingestion, intravenous injection and dermal penetration into the body, and distributed in the vital organs such as lymph nodes, brain, lung, liver and kidney (Wang et al., 2007; Shakeel et al., 2016). Some In vivo studies demonstrated that ultrafine anatase $\mathrm{TiO}_{2}$ particles could induce broncheo-alveolar lavage inflammatory and cell proliferation (Warheit et al., 2007). These nanomaterials are rapidly distributed in organs and tissues after injection and can pass into the cells (Mahdieh et al., 2016). In addition, $\mathrm{TiO}_{2}$ NPs have the potential to cross biological barriers such as blood-brain barrier and blood-placenta barrier to reach different organs and tissues (Song et al., 2015). Several studies reported $\mathrm{TiO}_{2}$ NPs accumulation in several organs of experimental animals mainly the liver, kidneys, spleen, lymph node, lungs, and heart, and could not be cleared from the liver and kidney before 15 days after administration (Chen et al., 2009; Li \& Chen, 2011). Hepatic injury was also observed in female mice treated with $\mathrm{TiO}_{2}$ NPs, included hydropic degeneration, hepatocytes spotty necrosis; renal damage including swelling of the renal glomerulus. In their recent stuy, Chang et al. (2013) reviewed 347 reports on $\mathrm{TiO}_{2}$ NPs toxicity indicated the presence of nano- $\mathrm{TiO}_{2}$ in various vital organs, such as liver, kidney, spleen and brain. In addition, the testicular tissue of mice treated with $\mathrm{TiO}_{2} \mathrm{NPs}_{\text {demonstrated }}$ sever congestion, edema, seminiferous tubules disturbance, vacuolation and necrosis in the germinal epithelium, reduction in sperm density and motility, sperm morphological abnormalities and germ cell apoptosis together with alteration in the serum value of testosterone, LH and FSH (Morgan et al., 2015; Abdulla, 2017).

Due to the growing number of applications, more concerns are raised for the potential risk to $\mathrm{TiO}_{2} \mathrm{NPs}$ exposure in human health and the environment (Yang et al.). These concerns need to be investigated in order to provide a scientific evidence for a safe utilization of nanotechnologies. Little, if any, is known about the toxicity of $\mathrm{TiO}_{2} \mathrm{NPs}$ on the renal tissues, accordingly, the current work aims to investigate the alterations that may be induced by $\mathrm{TiO}_{2} \mathrm{NPs}$ on renal tissues.

\section{MATERIAL AND METHOD}

Nanoparticle. Titanium dioxide nanoparticles (APS $<25$ $\mathrm{nm}$ ), were purchased from Sigma-Aldrich (USA).

Experimental Animals. A total of 40 healthy male Wistar albino rats (Rattus norvegicus) of the same age (12 weeks old) and weighing 220-250 g were obtained from the Ani- mal Care Center, College of Pharmacy, King Saud University.

$\mathrm{TiO}_{2}$ Nanoparticle Preparation. Titanium dioxide NPs were suspended in $(0.9 \% \mathrm{NaCl}$ solution) at a concentration of $1 \mathrm{mg} / \mathrm{ml}$.

Experimental Design. The rats were housed in stainlesssteel cages under a regulated light and dark schedule on a $12 \mathrm{~h}$ day/night cycle and controlled ventilation, humidity and temperature $24 \pm 3{ }^{\circ} \mathrm{C}$ and fed with standard laboratory rodent pelleted feed and water ad libitum. Animals were examined for health status and acclimated to the laboratory environment for one week prior to use. All the experiments were conducted in accordance with the standard animal ethics and the study protocol was reviewed and approved by the ethical committee of Faculty of Medicine, Sana'a University. Selection of doses for $\mathrm{TiO}_{2} \mathrm{NPs}$ was based on previous studies (Park et al., 2008; Zhang et al., 2010). The current study was conducted in order to compare the toxicity of NPs at three different doses of 126, 252 and $378 \mathrm{mg} / \mathrm{kg} \mathrm{b}$ w for 24 and $48 \mathrm{~h}$. The animals were divided into four groups of ten rats each, intraperitoneally administered at the rate of 2 days as follows:

Group I: Control animals received the vehicle (normal saline).

Group II: Received infusion of $126 \mathrm{mg} / \mathrm{kg} \mathrm{TiO}{ }_{2} \mathrm{NPs}$ for 24 and $48 \mathrm{~h}$.

Group III: Received infusion of $252 \mathrm{mg} / \mathrm{kg} \mathrm{TiO}{ }_{2}$ NPs for 24 and $48 \mathrm{~h}$.

Group IV: Received infusion of $378 \mathrm{mg} / \mathrm{kg} \mathrm{TiO} \mathrm{NPs}_{2}$ for 24 and $48 \mathrm{~h}$.

Five animals from each group were euthanized at intervals of 24 and $48 \mathrm{~h}$ of treatment with $\mathrm{TiO}_{2} \mathrm{NPs}$. All experiments were performed according to the guidelines approved by King Saud University, Local Animal Care and Use Committee.

Histological Processing. Fresh portions of the kidney from each rat were cut rapidly, fixed in neutral buffered formalin $(10 \%)$, then dehydrated, with grades of ethanol $(70,80,90,95$ and $100 \%)$. Dehydration was then followed by clearing the samples in 2 changes of xylene, impregnated with 2 changes of molten paraffin wax, then embedded and blocked out. Paraffin sections $(4-5 \mu \mathrm{m})$ were stained and examined alterations in the renal tissues of each rat under study by using optical microscope (Olympus Microscope BX51 with Digital Camera, Japan). 


\section{RESULTS AND DISCUSSION}

No mortality occurred in any of the investigated groups of the present study. In comparison with the control animals, the following histological alterations were detected.

Control Rats. The architecture in the kidney of all control rats demonstrated well preserved and kept intact normal histological components of the glomeruli, renal tubules and interstitial tissues of both the cortex and the medulla (Fig. 1).

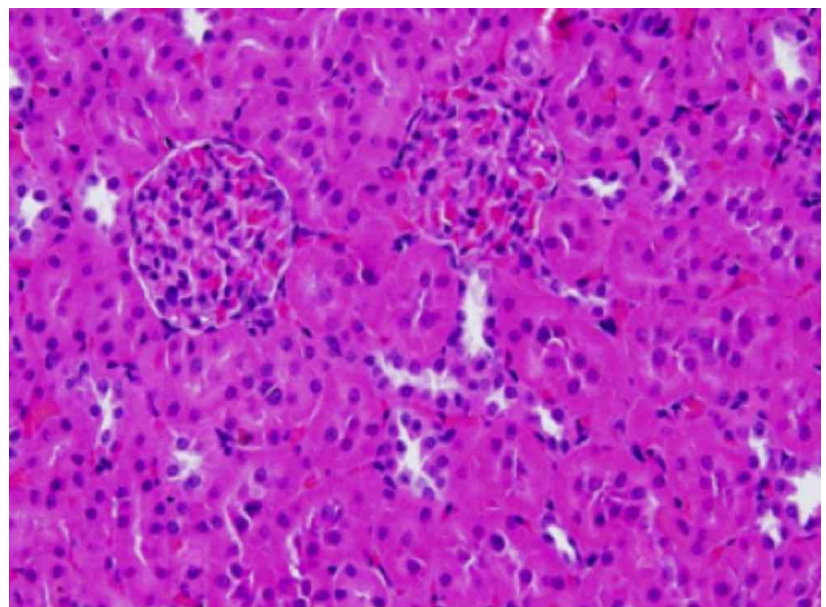

Fig. 1. Light micrographs in kidney of control rat received normal saline $(1 \mathrm{ml} / \mathrm{kg} /$ day for $48 \mathrm{~h})$ demonstrating normal histological architecture. H \& E stain. 400x.

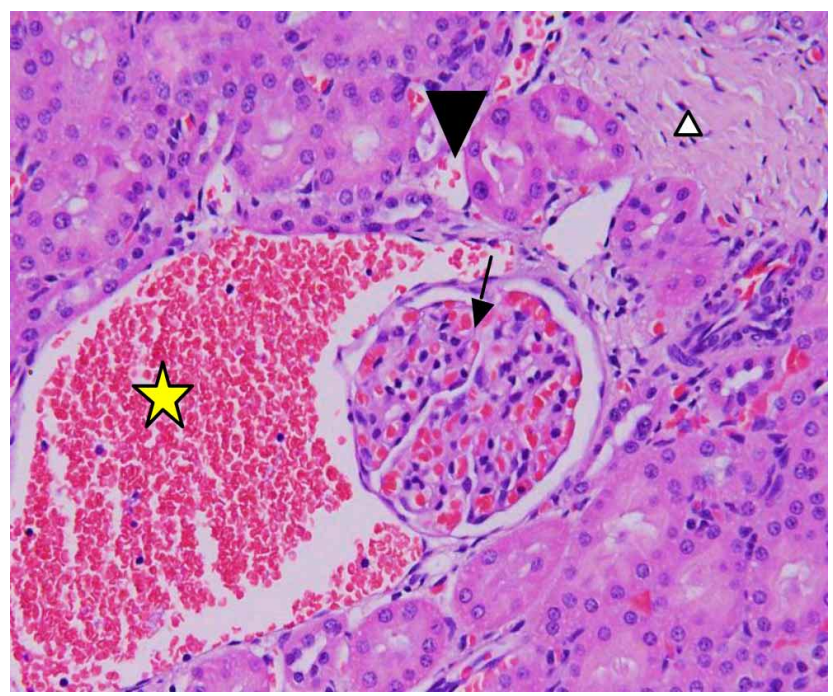

Fig. 2. Light micrograph in kidney of rat exposed to $378 \mathrm{mg} / \mathrm{kg}$ $\mathrm{TiO} 2 \mathrm{NPs}$ for $24 \mathrm{~h}$, demonstrating glomerular congestion (arrow). Note the vascular dilatation $(*)$, hyaline-like materials (arrow head) and fibrosis (triangle). $\mathrm{H} \& \mathrm{E}$ stain, 400x.

$\mathrm{TiO}_{2}$ NPs-treated Rats. The kidneys of rats exposed to $\mathrm{TiO}_{2}$ NPs for 24 or $48 \mathrm{~h}$ showed renal histological and histochemical alterations included the glomeruli, renal tubules and intracellular tissues.

Glomerular Congestion: Occasional moderate glomerular congestion was demonstrated by the renal tissues of rats exposed to $378 \mathrm{mg} / \mathrm{kg} \mathrm{TiO}{ }_{2} \mathrm{NPs}$ for $48 \mathrm{~h}$ (Fig. 2). This alteration was not observed in the kidneys of rats received 126 or $252 \mathrm{mg} / \mathrm{kg} \mathrm{TiO}{ }_{2} \mathrm{NPs}$ for 24 or $48 \mathrm{~h}$. It was reported that the renal glomerular basement membrane is fragile and sensitive to toxic effects of NPs (Yang et al.).

Bowman's Capsule Swelling and Dilatation. This damage was seen in the kidneys of rats received $252 \mathrm{mg} / \mathrm{kg}$ and more of $\mathrm{TiO}_{2} \mathrm{NPs}$ for $24 \mathrm{~h}$ or more

This alteration may indicate dissociation of junctions between the glomeruli and the renal tubule and might be associated with free radicals induced by $\mathrm{TiO}_{2} \mathrm{NPs}$ exposure. (Fig. 3).

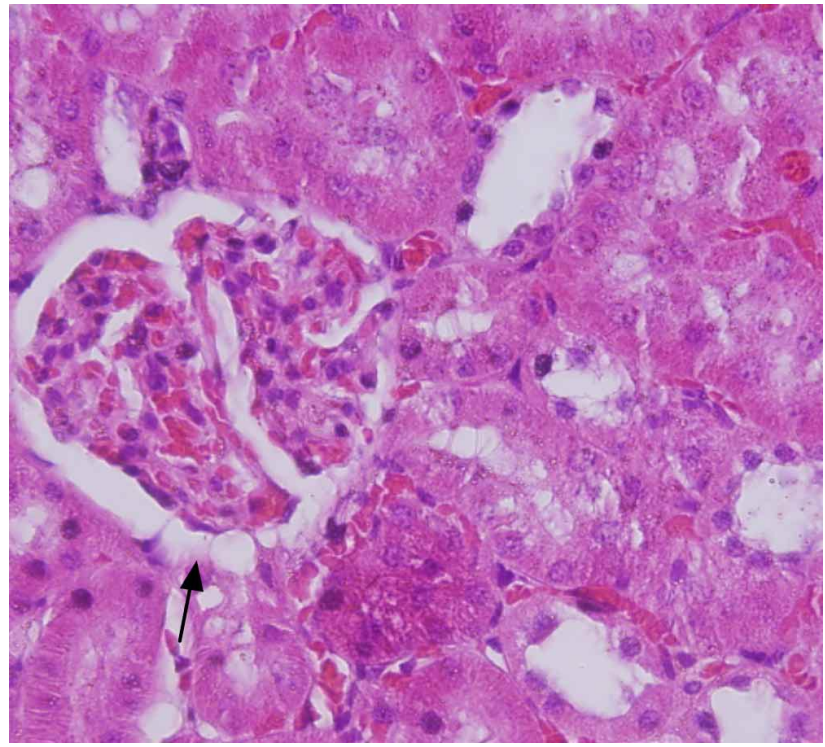

Fig. 3. Light micrograph in kidney of rat exposed to $378 \mathrm{mg} / \mathrm{kg}$ $\mathrm{TiO}_{2}$ NPs for $48 \mathrm{~h}$, demonstrating Bowman's capsule swelling and dilatation (arrow). H \& E stain, 600×.

Inflamed Glomeruli: Occasional inflamed glomeruli were seen in the kidneys of rats received $\mathrm{TiO}_{2}$ NPs for $48 h$ (Fig. 4). This alteration was not demonstrated in the renal tissues of rats subjected to nanomaterials for $24 h$. This may indicate that exposure to $\mathrm{TiO}_{2} \mathrm{NPs}$ can cause glomerulonephritis leading to renal failure due to glomerular damage characterized by protein leakage into urine.

Hydropic Degeneration: Vacuolated swelling of the cytoplasm of renal cells of the NPs-treated rats was seen in the renal tissues of all rats subjected to $\mathrm{TiO}_{2} \mathrm{NPs}$ with varia- 


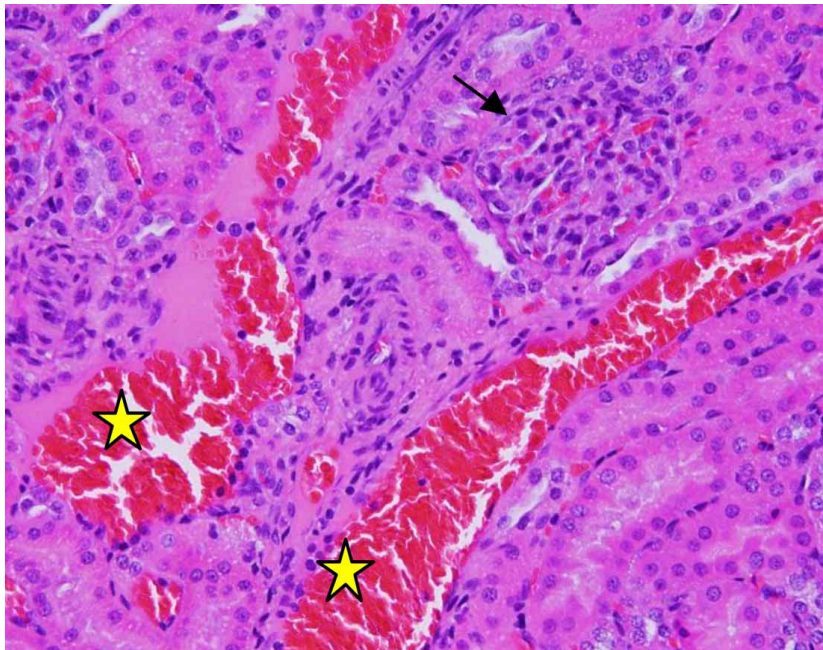

Fig. 4. Light micrograph in kidney of rat exposed to $378 \mathrm{mg} / \mathrm{kg}$ $\mathrm{TiO}_{2} \mathrm{NPs}$ for $48 \mathrm{~h}$, demonstrating inflamed glomeruli (arrow). Note blood vessels congestion and dilatation (*). H \& E stain, 400x.

ble impacts in respect to dose and exposure duration (Fig. $5 \mathrm{a}-\mathrm{c})$. This might be resulted from ion and fluid homeostasis imbalance that lead to an increase of intracellular water together with massive influx of water and $\mathrm{Na}^{+}$due to acute kidney injury induced by these NPs leading to lysosomal hydrolytic enzyme leakages and cellular degeneration (Schrand et al., 2010). The small size and clearance delay of $\mathrm{TiO}_{2} \mathrm{NPs}$ from the body, may lead to the retention and accumulation of these particles in the renal tissues. It was reported that at least two weeks are needed for respiratory exposure to ultrafine $\mathrm{TiO}_{2}$ aerosols $\left(0.8 \mu \mathrm{m}, 10 \mathrm{mg} / \mathrm{m}^{3}\right)$ for out excretion by the kidneys (Wang et al.). Titanium dioxide nanomaterials were observed to translocate into the blood, following oral or intraperitoneal exposure, and thereafter distribute to secondary targets, including the liver, spleen, lungs, and kidneys (Wang et al.; Johnston et al., 2009).

Necrosis: Focal massive necrotic degeneration was demonstrated in the renal cells of the proximal convoluted tubules of rats exposed to $\mathrm{TiO}_{2}$ NPs (Fig. 6). This alteration was less prominent in the renal tissues of animals subjected to $126 \mathrm{mg} / \mathrm{kg} \mathrm{TiO}{ }_{2} \mathrm{NPs}$ for $24 \mathrm{~h}$, in comparison with the ones received 252 or $378 \mathrm{mg} / \mathrm{kg}$ and rats treated for $48 \mathrm{~h}$ by the NPs. Moreover, this alteration was more prominent in the cortex than the medulla. Cellular degeneration may be associated with spillage of lysosomal enzymes within the cell (Del Monte, 2005). Vacuolated degeneration is an effect of particle, ions and fluid homeostasis that prompt an
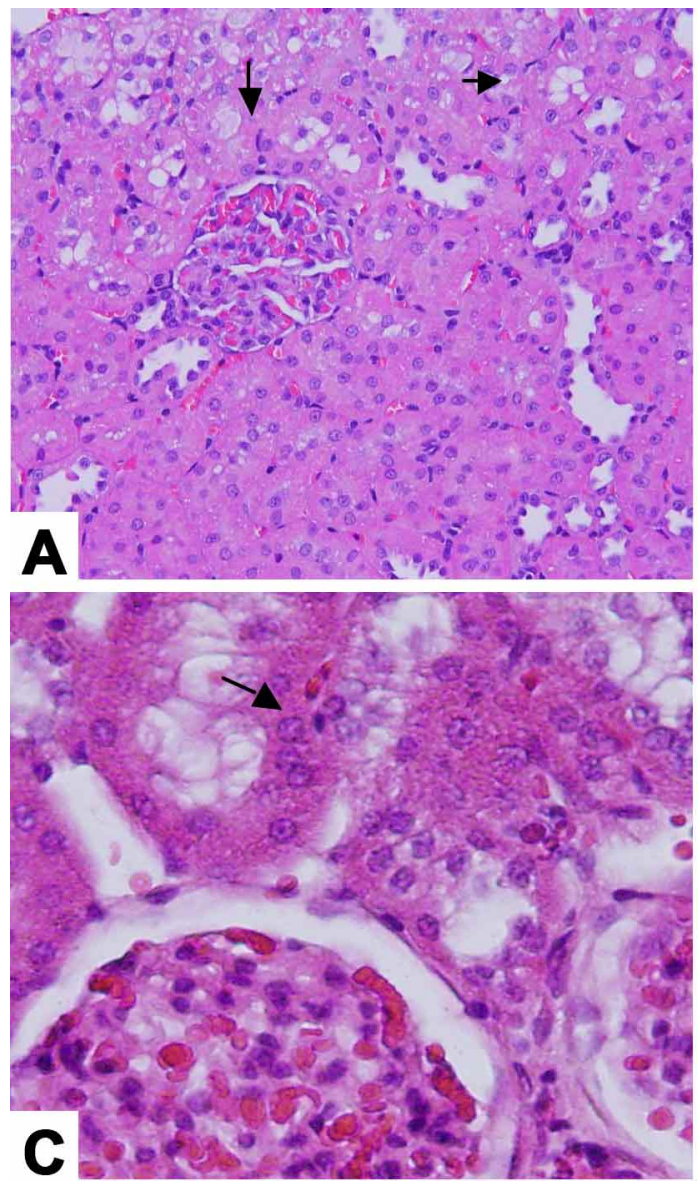

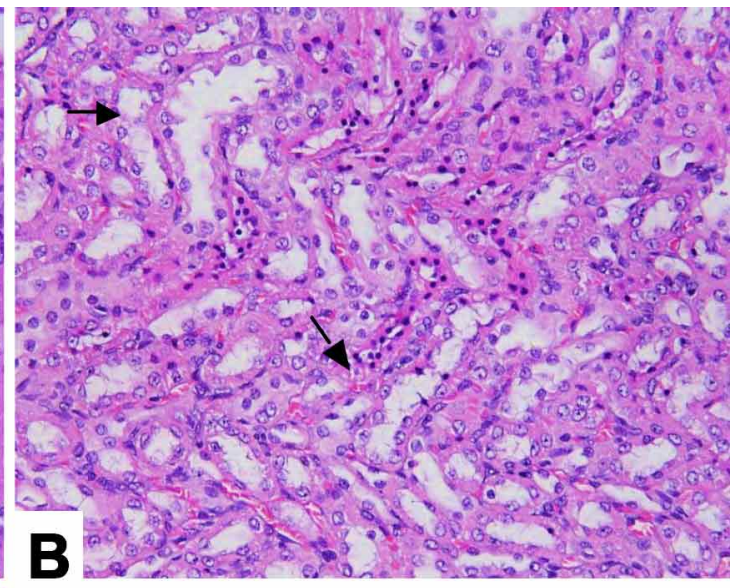

Fig. 5(a-c). Light micrograph in kidney of rat exposed to $\mathrm{TiO}_{2}$ NPs demonstrating hydropic degeneration (arrows) at variable doses and durations of exposure: (a). $126 \mathrm{mg} / \mathrm{kg} \mathrm{TiO}{ }_{2} \mathrm{NPs}$ for $48 \mathrm{~h}, \mathrm{H} \& \mathrm{E}$ stain, $400 \times$. (b). $252 \mathrm{mg} / \mathrm{kg} \mathrm{TiO}{ }_{2} \mathrm{NPs}$ for $24 \mathrm{~h}, \mathrm{H} \& \mathrm{E}$ stain, $400 \times$. (c). $378 \mathrm{mg} / \mathrm{kg} \mathrm{TiO}{ }_{2}$ NPs for $48 \mathrm{~h}$. H \& E stain, $1000 \times$. 


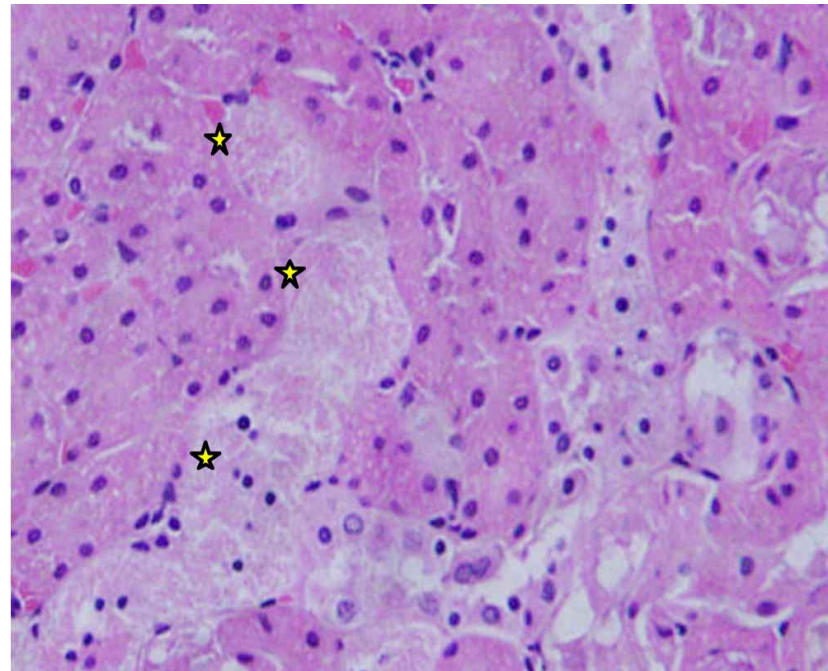

Fig. 6. Light micrograph in kidney of rat exposed to $\mathrm{TiO}_{2} \mathrm{NPs}$ $\left(378 \mathrm{mg} / \mathrm{kg}\right.$ ) for $48 \mathrm{~h}$ demonstrating necrotic renal tubules ${ }^{2}$ (*). $\mathrm{H}$ \& E stain. 600x

increasing of intracellular water (Schrand et al.). Moreover, the demonstrated renal necrosis might indicate oxidative stress by glutathione depletion as a result of $\mathrm{TiO}_{2} \mathrm{NPs}$ toxicity.

Renal Tubules Cloudy Swelling: The epithelial lining of the renal cell of rats subjected to $\mathrm{TiO}_{2}$ NPs $(252 \mathrm{mg} / \mathrm{kg}$ or more for $24 \mathrm{~h}$ or more) showed cloudy swelling (Fig. 7). This alteration may indicate that acute renal injury could induce disturbances of membranes function that lead to leakage and accumulation of water due to $\mathrm{TiO}_{2}$ NPS toxicity and cytoplasmic degeneration and macromolecular crowding (Abdelhalim \& Jarrar, 2011).

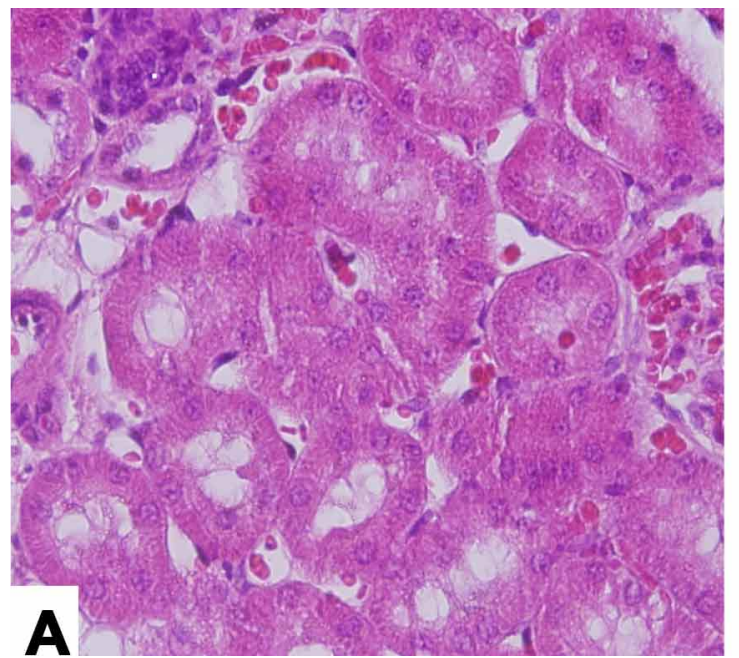

Renal Cells Nuclear Alterations: Some renal cells in the lining epithelia of the proximal convoluted tubule of NPstreated rats demonstrated karyorrhexis or/and karyolysis (Fig. 8a-b). This may indicate oxidative stress induced by $\mathrm{TiO}_{2}$ NPs exposure. Karyorrhexis and karyolysis are destructive fragmentation and complete dissolution of the chromatin matter of a necrotic or dying cell.

Hyaline Droplets and Hyaline Casts: Luminal hyaline casts and cytoplasmic droplets were demonstrated by the kidneys of rats received $378 \mathrm{mg} / \mathrm{kg} \mathrm{TiO}$ and to lesser extent in the renal tissues of those received $252 \mathrm{mg} / \mathrm{kg} \mathrm{TiO}{ }_{2} \mathrm{NPs}_{\text {for }} 48 \mathrm{~h}$ (Fig. 9a-c). This damage was not seen in the renal tissues of animals exposed to $126 \mathrm{mg} / \mathrm{kg} \mathrm{TiO}_{2} \mathrm{NPs}_{\text {for }} 24 h$ or $48 \mathrm{~h}$.

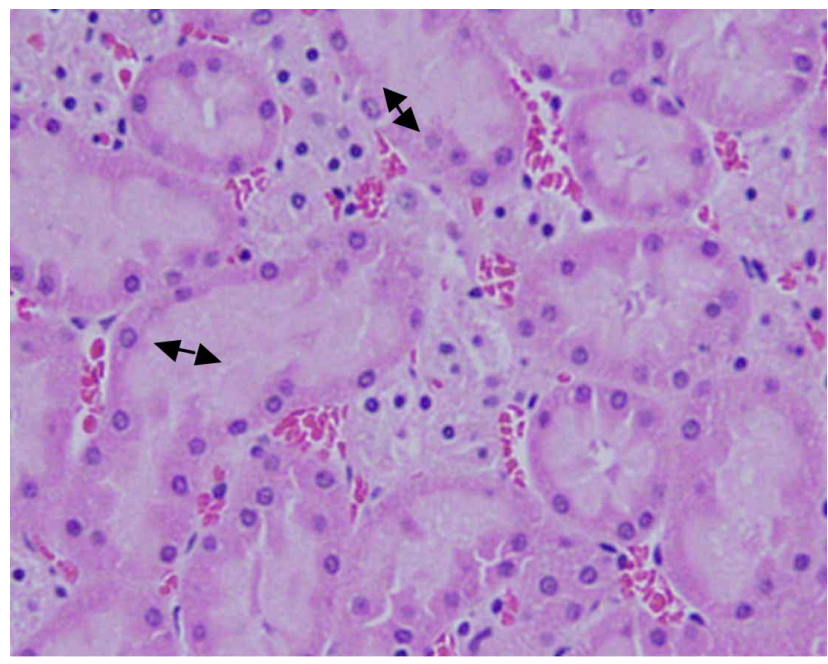

Fig. 7. Light micrograph in kidney of rat exposed to $\mathrm{TiO}_{2} \mathrm{NPs}$ $(378 \mathrm{mg} / \mathrm{kg}$ ) for $48 \mathrm{~h}$ showing cloudy swelling (double-headed arrows). H \& E stain. 600x.

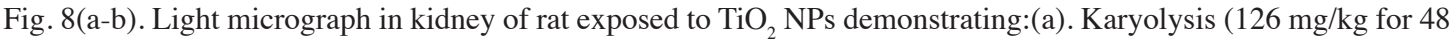
h), H\&E stain. $600 \times$ (b). Karyorrhexis (arrow) $(252 \mathrm{mg} / \mathrm{kg}$ for $24 \mathrm{~h}), \mathrm{H} \& \mathrm{E}$ stain. $1000 \times$. 


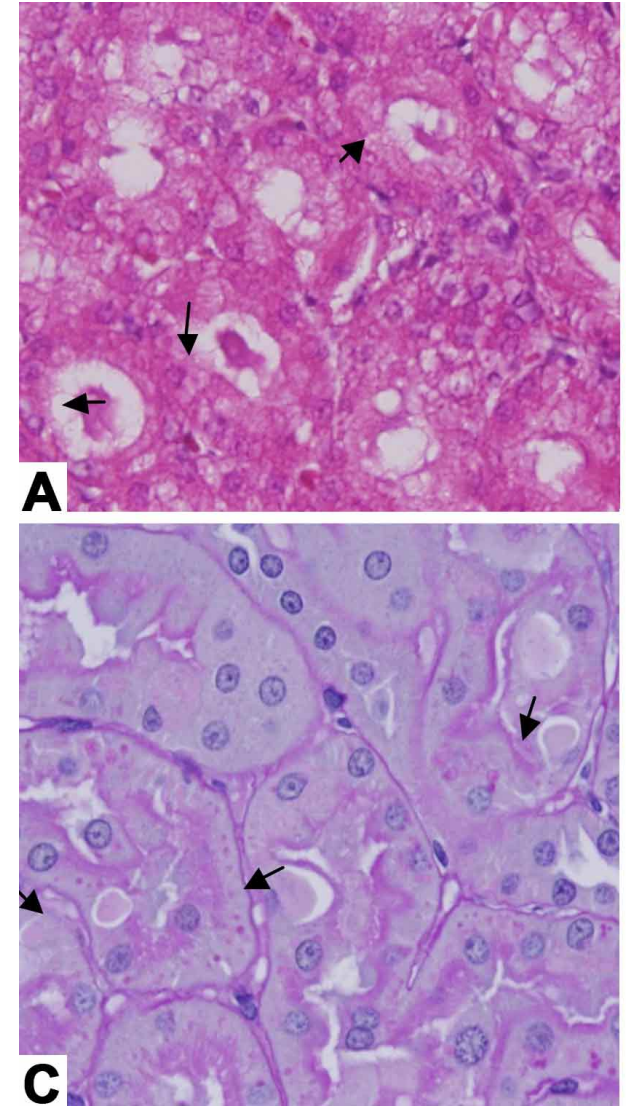

Moreover, occasional hyaline casts were also seen in the lumen of some cortical distal convoluted renal tubules. The precipitations hyaline droplets in the renal cells and hyaline casts in the renal tubules lumen might be associated with protein metabolism disturbances (Abdelhalim \& Jarrar).

Inflammatory Cells Infiltration: All members subjected to $\mathrm{TiO}_{2} \mathrm{NPs}$ for $24 h$ and more demonstrated inflammatory cells infiltration (Fig. 10a-c). This change may suggest that $\mathrm{TiO}_{2}$ NPs may interfere with the antioxidant defense mechanism and induce oxidative stress in the renal tissue leading to induction of inflammatory response. Sutariya \& Pathak (2015) reported that metallic nature of most inorganic nanoparticles could cause inflammatory cells infiltration in the tissues of vital organs. The cytotoxic potential of $\mathrm{TiO}_{2}$ NPs is related with production of ROS that induce damage to DNA through breakage and oxidation of nucleotides (Johar et al., 2004).

Cortical Blood Vessels Dilatation and Congestion: In comparison with the control group, the cortex of rats exposed

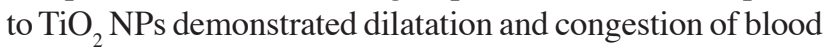
capillaries (Fig. 11). This alteration was more prominent in the renal tissues of rats exposed to $378 \mathrm{mg} / \mathrm{kg} \mathrm{TiO}{ }_{2} \mathrm{NPs}$ for $48 \mathrm{~h}$ than the members of the other groups subjected to 252 or $378 \mathrm{mg} / \mathrm{kg} \mathrm{TiO}_{2} \mathrm{NPs}$ for $24 \mathrm{~h}$. This alteration could be

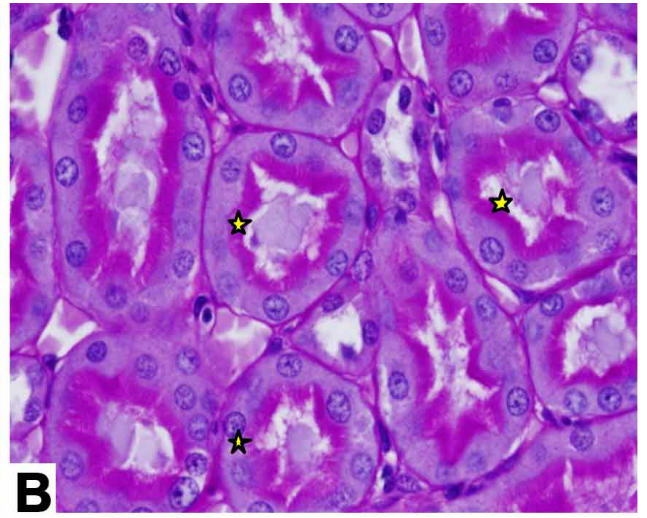

Fig. 9(a-c): Light micrograph in kidney of rat exposed to $\mathrm{TiO}_{2} \mathrm{NPs}$ demonstrating:

(a). Hyaline casts (arrows), $\left(252 \mathrm{mg} / \mathrm{kg} \mathrm{TiO}_{2} \mathrm{NPs}\right.$ for 48 hrs) (arrows). H\&E stain, 1000x.

(b). Hyaline casts $(*),\left(378 \mathrm{mg} / \mathrm{kg} \mathrm{TiO}_{2} \mathrm{NPs}\right.$ for 48 hrs) (stars). PAS stain, 1000x.

(c). Hyaline droplets (arrows), $\left(378 \mathrm{mg} / \mathrm{kg} \mathrm{TiO}{ }_{2} \mathrm{NPs}\right.$ for $48 \mathrm{~h}$ ) (arrows). PAS stain, 1000x.

resulted from the vasodilator effect of these nanomaterials and might indicate impact in the cell membrane permeability of renal blood vessels endothelia (Johnson, 1995). On the other hand, medullar blood vessels were almost not affected by $\mathrm{TiO}_{2} \mathrm{NPs}$ exposure.

Edema: The kidneys of rats exposed to $378 \mathrm{mg} / \mathrm{kg} \mathrm{TiO}_{2} \mathrm{NPs}$ revealed swelling of intertubular tissues mainly surrounding the renal blood vessels (Fig. 12). Renal edema is swelling caused by excess fluids accumulation in the intertubular tissues where he nephrones become no longer able to filter urine out of blood plasma. In addition, chronic renal tissues swelling is an indicator of plasma albumin declining and interstitial fluid accumulation that may lead to nephritic syndrome.

Fibrosis: Tubulointerstitial renal failure was demonstrated by rats exposed to $252 \mathrm{mg} / \mathrm{kg}$ and more of $\mathrm{TiO}_{2}$ NPs (Fig. 13). This irreversible parenchymal scar is a primary cause of renal failure.

The findings of the present study indicated that the cortex and the proximal convoluted tubules were more affected by $\mathrm{TiO}_{2}$ NPs than the medulla and the distal ones. This may indicate that more of these nanomaterials circulate and precipitate in the cortical tissues via the blood stream than that would reach the medulla. 

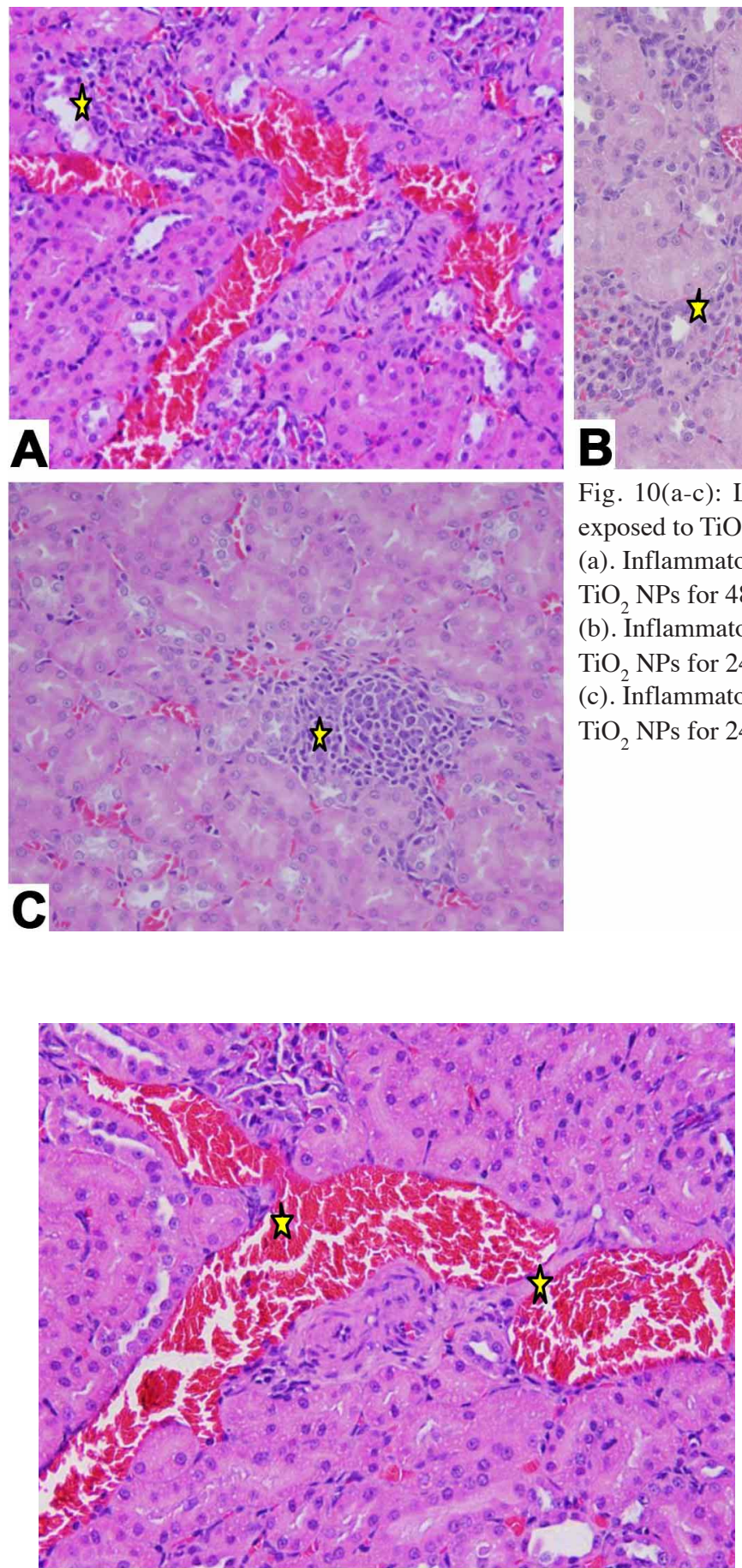

Fig. 11. Light micrograph in kidney of rat exposed to $\mathrm{TiO}_{2} \mathrm{NPs}$ $(378 \mathrm{mg} / \mathrm{kg})$ for $24 \mathrm{~h}$ demonstrating marked cortical dilation of congested blood vessels (*). H \& E, 400x.

Fig. 13. Light micrograph in kidney of rat exposed to $\mathrm{TiO}_{2} \mathrm{NPs}$ $(252 \mathrm{mg} / \mathrm{kg}$ ) for $48 \mathrm{~h}$ demonstrating fibrosis (*). Mallory trichrome stain, 400x.

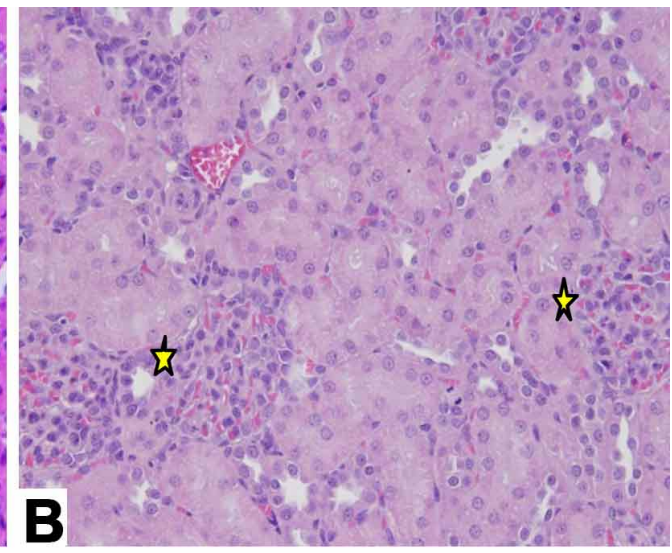

Fig. 10(a-c): Light micrograph in kidney of rat exposed to $\mathrm{TiO}_{2} \mathrm{NPs}$

(a). Inflammatory cells infiltration $(*),(126 \mathrm{mg} / \mathrm{kg}$ $\mathrm{TiO}_{2}$ NPs for $48 \mathrm{~h}$ ) (arrows). H \& E, 400, 400×. (b). Inflammatory cells infiltration (*), $(252 \mathrm{mg} / \mathrm{kg}$ $\mathrm{TiO}_{2}$ NPs for $24 \mathrm{~h}$ ) (arrows). H \& E stain, 400x. (c). Inflammatory cells infiltration $(*),(378 \mathrm{mg} / \mathrm{kg}$ $\mathrm{TiO}_{2}$ NPs for $24 \mathrm{~h}$ ) (arrows). H \& E stain, 400x.

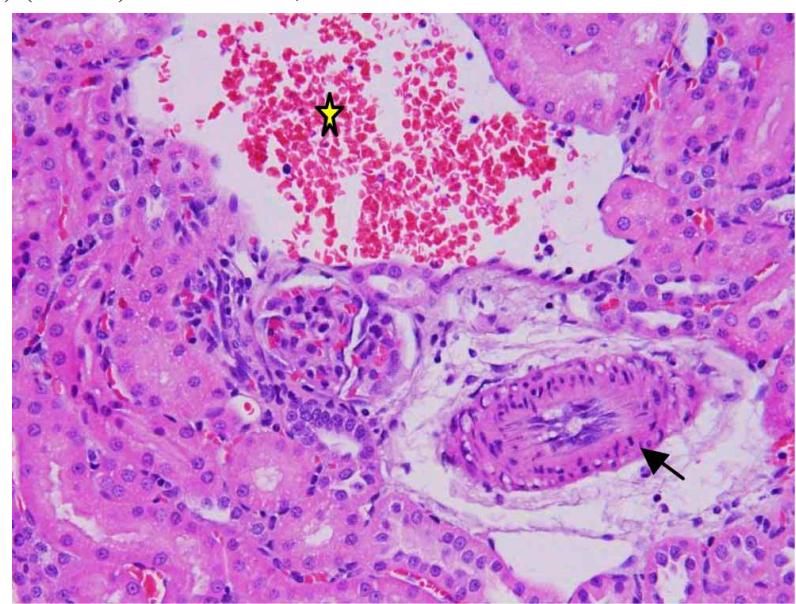

Fig. 12. Light micrograph in kidney of rat exposed to $\mathrm{TiO}_{2} \mathrm{NPs}$ $(378 \mathrm{mg} / \mathrm{kg}$ ) for $24 \mathrm{~h}$ demonstrating edema (arrow) with marked cortical dilation of congested blood vessels (*).H \&E stain. 400×.

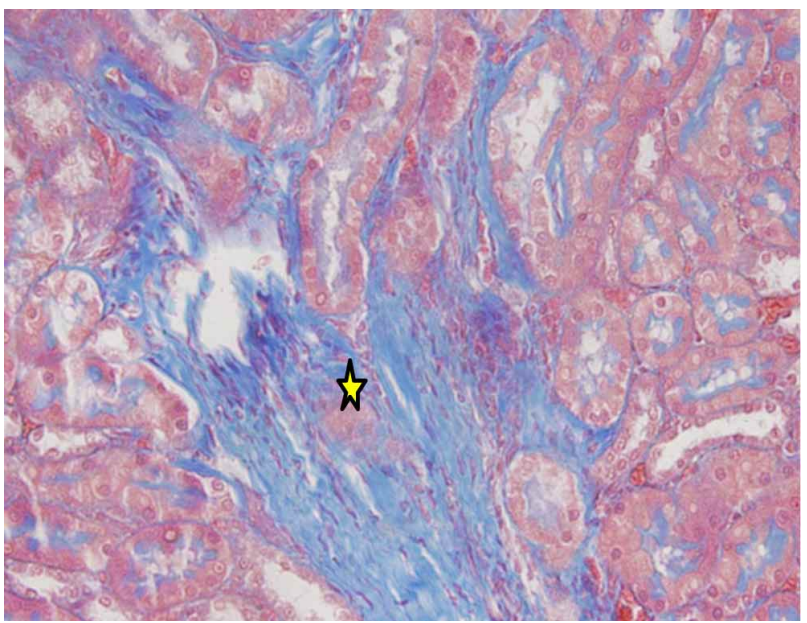




\section{CONCLUSION}

The current work demonstrated nanotoxic histological alterations after acute $\mathrm{TiO}_{2} \mathrm{NPs}$ exposure. One may conclude from the present study findings that these nanomaterials could cause marked histological alterations in the renal tissues affecting the functions of the kidneys and other vital organs. This renal damage might be resulted from the oxidative stress induced by these particles and the interference with the membrane structure, and macromolecules of the renal cell. More investigations are recommended on the nantoxicity of these particles.

\section{ACKNOWLEDGMENTS}

The authors would like to extend their sincere appreciation to King Saud University, Sana'a University and Jerash University for putting the needed facilities under their disposal.

AL-DOAISS, A. A.; ALI, D.; ALI, B. A. \& JARRAR, B. M. Alteraciones histológicas renales inducidas por la exposición aguda de nanopartículas de dióxido de titanio. Int. J. Morphol., 37(3):1049.1057, 2019.

RESUMEN: Las nanopartículas de dióxido de titanio $\left(\mathrm{TiO}_{2} \mathrm{NP}\right)$ se usan ampliamente en muchos productos comerciales, nanomedicina, agricultura, productos para el cuidado personal, diferentes industrias y preparaciones farmacéuticas con riesgo potencial para la salud humana y el medio ambiente. El trabajo actual se realizó para investigar el daño renal que podría ser inducido por la toxicidad aguda $\mathrm{NP}$ de $\mathrm{TiO}_{2}$. Un total de 40 ratas Wistar albinas adultas sanas (Rattus norvegicus) fueron expuestas a $\mathrm{TiO}_{2} \mathrm{NP}(126,252,378 \mathrm{mg} / \mathrm{kg}$ de peso corporal) durante 24 y $48 \mathrm{~h}$. Las muestras de los riñones de las ratas se procesaron para estudios histológicos e histoquímicos. En comparación con las ratas control, la exposición de las ratas a $\mathrm{TiO}_{2} \mathrm{NP}$ presentaron las siguientes alteraciones glomerulares, tubulares e intersticiales: congestión glomerular, dilatación de la cápsula de Bowman, inflamación glomerular, túbulos renales aumentados, cariorrexis, cariólisis, infiltración de células inflamatorias, congestión, necrosis, degeneración hidrópica, dilatación y congestión de vasos sanguíneos, gotas y precipitaciones hialina, edema intersticial y fibrosis. A partir de los hallazgos del trabajo actual, se puede concluir que las $\mathrm{NP}$ de $\mathrm{TiO}_{2}$ son capaces de inducir daño renal con más aislamiento en la corteza y en los túbulos contorneados proximales que en la médula y los túbulos contorneados distales, respectivamente. Además, se podría concluir que el daño renal inducido por estos nanomateriales depende de la dosis y la duración de la exposición. Se recomiendan estudios adicionales hematológicos, bioquímicos, inmunohistoquímicos y ultraestructurales.

PALABRAS CLAVE: Nanopartículas de $\mathrm{TiO}_{2}$; Tejidos renales; Alteraciones histológicas; Degeneracion hidrópica; Nanotoxicidad.

\section{REFERENCES}

Abdelhalim, M. A. \& Jarrar, B. M. Renal tissue alterations were sizedependent with smaller ones induced more effects and related with time exposure of gold nanoparticles. Lipids Health Dis., 10:163, 2011.

Abdulla, I. T. Histological effects of titanium dioxide nanoparticles size 10 $\mathrm{nm}$ in mice testes. Sci J. Univ. Zakho, 5(2):158-61, 2017.

Chabanyuk, Y. Assessing Toxicity of Titanium Dioxide $\left(\mathrm{TiO}_{2}\right)$ Nanoparticles on Pseudomonas Species Biofilms. Thesis. Toronto, Ryerson University, 2014

Chang, X.; Zhang, Y.; Tang, M. \& Wang, B. Health effects of exposure to nano-TiO ${ }^{2}$ : a meta-analysis of experimental studies. Nanoscale Res. Lett., 8(1):51, 2013.

Chen, J.; Dong, X.; Zhao, J. \& Tang, G. In vivo acute toxicity of titanium dioxide nanoparticles to mice after intraperitioneal injection. J. Appl. Toxicol., 29(4):330-7, 2009.

Del Monte, U. Swelling of hepatocytes injured by oxidative stress suggests pathological changes related to macromolecular crowding. Med. Hypotheses, 64(4):818-25, 2005.

Fartkhooni, F. M.; Noori,A. \& Mohammadi,A. Effects of titanium dioxide nanoparticles toxicity on the kidney of male rats. Int. J. Life Sci., 10(1):65-9, 2016.

Galletti, A. Toxicity Evaluation of TiO2 Nanoparticles Embedded in Consumer Products. Thesis. Miami, University of Miami, 2016.

Johar, D.; Roth, J. C.; Bay, G. H.; Walker, J. N.; Kroczak, T. J. \& Los, M. Inflammatory response, reactive oxygen species, programmed (necroticlike and apoptotic) cell death and cancer. Rocz. Akad. Med. Bialymst., 49:31-9, 2004.

Johnston, H. J.; Hutchison, G. R.; Christensen, F. M.; Peters, S.; Hankin, S. $\&$ Stone, V. Identification of the mechanisms that drive the toxicity of $\mathrm{TiO}_{2}$ particulates: the contribution of physicochemical characteristics. Part Fibre Toxicol., 6:33, 2009.

Li, J. J.; Muralikrishnan, S.; Ng, C. T.; Yung, L. Y. \& Bay, B. H. Nanoparticleinduced pulmonary toxicity. Exp.Biol.Med.(Maywood), 235(9):1025$33,2010$.

Li, Y. F. \& Chen, C. Fate and toxicity of metallic and metal-containing nanoparticles for biomedical applications. Small, 7(21):2965-80, 2011.

Mahdieh, Y.; Sajad, S.; Mahmoudreza, G.; Ali, B.; Hossein, D.; Mohammad, A. \& Mehrdad, M. The effects of titanium dioxide nanoparticles on liver histology in mice. J. Chem. Pharm. Res., 8(4):1313-6, 2016.

Morgan, A. M.; El-Hamid, M. I. A. \& Noshy, P. A. Reproductive toxicity investigation of titanium dioxide nanoparticles in male albino rats. World J. Pharm. Pharm. Sci., 4(10):34-49, 2015.

Park, E. J.; Yi, J.; Chung, K. H.; Ryu, D. Y.; Choi, J. \& Park, K. Oxidative stress and apoptosis induced by titanium dioxide nanoparticles in cultured BEAS-2B cells. Toxicol. Lett., 180(3):222-9, 2008.

Schrand, A. M.; Rahman, M. F.; Hussain, S. M.; Schlager, J. J.; Smith, D. A.; Smith, D. A. \& Syed, A. F. Metal-based nanoparticles and their toxicity assessment. Wiley Interdiscip. Rev. Nanomed.Nanobiotechnol., 2(5):544-68, 2010.

Seeger, E. M.; Baun,A.; Kästner, M. \& Trapp, S. Insignificant acute toxicity of $\mathrm{TiO}_{2}$ nanoparticles to willow trees. J. Soils Sedim., 9(1):46-53, 2009.

Shakeel, M.; Jabeen, F.; Shabbir, S.; Asghar, M. S.; Khan, M. S.\& Chaudhry, A. S. Toxicity of nano-titanium dioxide $\left(\mathrm{TiO}_{2}-\mathrm{NP}\right)$ through various routes of exposure: a review. Biol. Trace Elem. Res. 172(1):1-36, 2016 
Song, B.; Liu, J.; Feng, X.; Wei, L. \& Shao, L. A review on potential neurotoxicity of titanium dioxide nanoparticles. Nanoscale Res. Lett., 10(1):1042, 2015.

Sutariya, V. B. \& Pathak, Y. Bio-interactions of nanomaterials. CRC Press. USA, 2015

Wang, J.; Zhou, G.; Chen, C.; Yu, H.; Wang, T.; Ma, Y.; Jia, G.; Gao, Y.; Li, B.; Sun, J.; et al. Acute toxicity and biodistribution of different sized titanium dioxide particles in mice after oral administration. Toxicol. Lett., 168(2):176-85, 2007.

Warheit, D. B.; Webb, T. R.; Reed, K. L.; Frerichs, S. \& Sayes, C. M. Pulmonary toxicity study in rats with three forms of ultrafine- $\mathrm{TiO}_{2}$ particles: differential responses related to surface properties. Toxicology, 230(1):90-104, 2007

Yang, Y.; Qin, Z.; Zeng, W.; Yang, T.; Cao, Y.; Mei, C. \& Kuang, Y. Toxicity assessment of nanoparticles in various systems and organs. Nanotechnol. Rev., 6(3):279-89, 2017.

Yuan, Y.; Ding, J.; Xu, J.; Deng, J. \& Guo, J. TiO nanoparticles co-doped with silver and nitrogen for antibacterial application. J. Nanosci. Nanotechnol., 10(8):4868-74, 2010.

Zhang, X. D.; Wu, H. Y.; Wu, D.; Wang, Y. Y.; Chang, J. H.; Zhai, Z. B.; Meng, A. M.; Liu, P. X.; Zhang, L. A. \& Fan, F. Y. Toxicologic effects of gold nanoparticles in vivo by different administration routes. Int. J. Nanomedicine, 5:771-81, 2010.

Zhao, J.; Ding, W. \& Zhang, F. Effect of nano-sized TiO2 particles on rat kidney function by metabonomic approach.J.Toxicol., 23:201-4, 2009.
Corresponding author:

Prof. Bashir M. Jarrar

Department of Biological Sciences

College of Science

Jerash University

Jerash 26150

JORDAN

Email: bashirjarrar@yahoo.com

Received: 19-12-2018

Accepted: 20-02-2019 